\title{
Proteomic analysis of soybean defense response induced by cotton worm (prodenia litura, fabricius) feeding
}

Rui Fan ${ }^{1,2}$, Hui Wang ${ }^{1}$, Yongli Wang ${ }^{1}$ and Deyue Yu ${ }^{1 *}$

\begin{abstract}
Background: Cotton worm is one of the main insects of soybean in southern China. Plants may acquire defense mechanisms that confer protection from predation by herbivores. Induced responses can lead to increased resistance against herbivores in many species. This study focuses on searching changed proteins in soybean defense response induced by cotton worm feeding.

Results: Ten protein spots that are changed in abundance in response to cotton worm feeding were identified by Two-dimensional gel electrophoresis (2-DE). A total of 11 unique proteins from these spots were identified by MALDI-TOF MS. The mRNA and protein relative expression levels of most changed proteins were up-regulated. These proteins were mainly involved in physiological processes, including active oxygen removal, defense signal transduction, and metabolism regulation.

Conclusion: This is the first proteomic analysis of the soybean defense response induced by cotton worm. The differentially expressed proteins could work together to play a major role in the induced defense response. PAL and SAMS were up-regulated at both the protein and mRNA levels. These genes can be strongest candidates for further functional research.
\end{abstract}

Keywords: Soybean, Induced resistance, 2-DE, qRT-PCR

\section{Background}

As an important economic crop, soybean provides significant sources of fatty acids, proteins, vitamins, minerals and other nutrients for humans and animals, and it also has nonfood uses, such as in the production of industrial feedstocks and combustible fuels $[1,2]$. However, insect pests can adversely affect the yield and quality of soybean. Cotton worm is one of the main insect pests of soybean in southern China [3,4]. Therefore, improvement in resistance to cotton worm is one of the main soybean breeding objectives.

During the process of evolution, plants have acquired defense mechanisms that confer protection from predation by herbivores. Two modes of resistance to herbivores exist: constitutive resistance, which is expressed

\footnotetext{
* Correspondence: dyyu@njau.edu.cn

${ }^{1}$ National Center for Soybean Improvement, National Key Laboratory of Crop Genetics and Germplasm Enhancement, Nanjing Agricultural University, Nanjing 210095, China

Full list of author information is available at the end of the article
}

independent of an attack; and induced resistance, which is activated only after the plant is attacked or otherwise injured [5]. Compared with constitutive resistance, induced resistance may be more durable and compromises plant fitness less by either decreasing further herbivore damage or increasing plant tolerance to herbivory [6]. Induced responses that lead to increased resistance against herbivores have been reported for over 100 species of plants, such as Arabidopsis [7-9], tobacco [10], tomato [11,12], rice [13], and soybean [14-16]. The resistance responses induced in plants change with different attackers. For example, the level of resistance induced by soybean looper herbivory with subsequent bean leaf beetle feeding was higher than that induced by bean leaf beetle herbivory with subsequent soybean looper feeding [16]. Resistance induced by the soybean looper, Mexican bean beetle and corn earworm in soybean has been reported in many studies [14-17]. 
However, induction of resistance in soybean by cotton worm has not been reported.

Many studies have investigated the induced defense response mechanism of plants. The plant hormones salicylic acid (SA), jasmonic acid (JA) and ethylene (ET) are the main players in the regulation of signaling networks involved in induced defense [18-21]. In general, pathogens are more sensitive to SA-dependent responses, whereas herbivorous insects and necrotrophic pathogens are resisted by JA/ET-dependent defenses [22-24]. Ample evidence indicates JA is the main signaling molecule that mediates a plant's defense system against herbivores $[19,23]$. A classic example is the observation that following attack by Manduca sexta larvae, tomato (Solanum lycopersicum) leaves accumulate JA, which results in the activation of genes encoding proteinase inhibitor proteins that inhibit digestive Ser proteinases of herbivorous insects and reduce further insect feeding $[8,25]$. Induced defense response mechanisms also involve the production of defensive compounds, such as proteinase inhibitors that affect insect feeding [25,26], volatile organic compounds that attract parasitoids and predators of the herbivores that feed on the plant $[18,27]$ and extrafloral nectar that arrests carnivorous arthropods on herbivore-infested plants [28].

Proteomics is a powerful tool for the study of protein dynamics, especially in plant stress responses [29,30]. Analysis of protein profiling is important to understand how genes/proteins are regulated. In the present study, we found that soybean resistance to cotton worm increased after induction of resistance by cotton worm feeding. To investigate which proteins are involved in this induced defense response, we used proteomic approaches to provide an overview of the cotton worm-induced defense response in soybean. Ten protein spots showed differential expression patterns in soybean leaves in response to cotton worm feeding, and 11 proteins were identified. Quantitative RT-PCR (qRT-PCR) analysis indicated differentially expressed proteins also showed changes in mRNA expression level.

\section{Results and discussion}

Induction of soybean defense response by cotton worm feeding

To determine whether cotton worm feeding can induce resistance in soybean leaves, we carried out a dual-choice test and force-feeding experiment (Figure 1). Compared with treated leaves, the cotton worm larvae preferred to eat control leaves, where PI $<1$ at the four sampling timepoints (Figure 1A). The relative growth rate of cotton worms feeding on control leaves was higher than those feeding on treated leaves except at $6 \mathrm{~h}$ (Figure 1B). In the force-feeding experiment, the relative growth rates of cotton worms feeding on control leaves and those feeding on treated leaves were similar. At this timepoint fifth-instar cotton worms were used, which eat greedily and were not sensitive to the food source [31]. In the dual-choice test and force-feeding experiment, the levels of induced resistance were slightly different at the four sampling timepoints, but these results still indicated that cotton worms can induce resistance in soybean.

Plants do not exhibit induced resistance to insects unless subjected to a certain degree of damage. In pre-experiments, soybean treated with cotton worm feeding shown induced resistance at a damage level of $20-30 \%$ and the levels of resistance were not increased significantly when the damage area increased. The capacity for induced resistance showed no difference also at a damage level between $15-45 \%$ in mountain birch [32]. However, when leaf damage constitutes $50 \%$ of the leaf area, induced resistance was produced in Quercus garryana [33]. The timing of induced resistance to herbivory is known to vary between plant species. Usually, in herbaceous plants, the longevity of induced resistance is several days [34-36]. The timing of induced resistance varied with the insect species feeding on soybean. The longevity of resistance induced by C. trifurcata was two weeks [16]. The induced response was effective for 3 days after damage against the Mexican bean beetle in soybean. After 15 days, the strength of resistance had declined and by 20 days, all four genotypes exhibited induced susceptibility [37]. In this study, the longevity of induced resistance produced by cotton worm was 5 days.
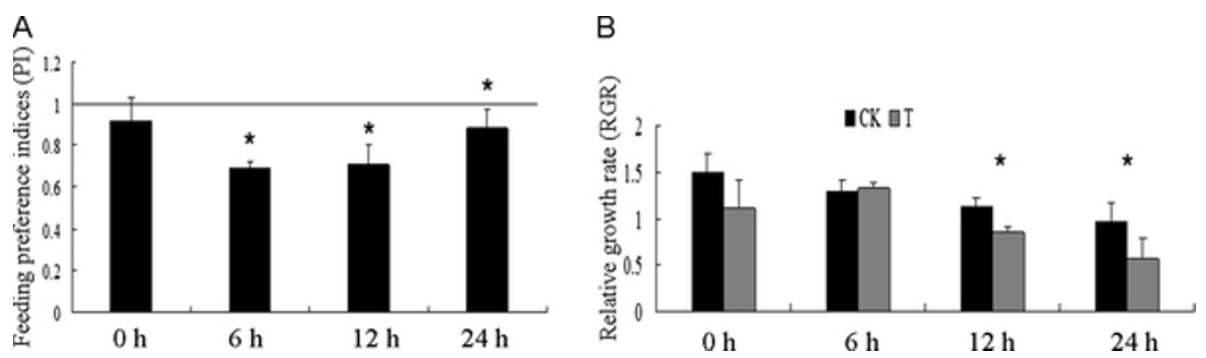

Figure 1 Identification of induced resistance. A, Feeding preference indices in dual-choice tests.B, Relative growth rate of cotton worms fed with control (CK) and treated (T) leaves. Error bars represent the standard deviation. * Significant $(P<0.05)$. 


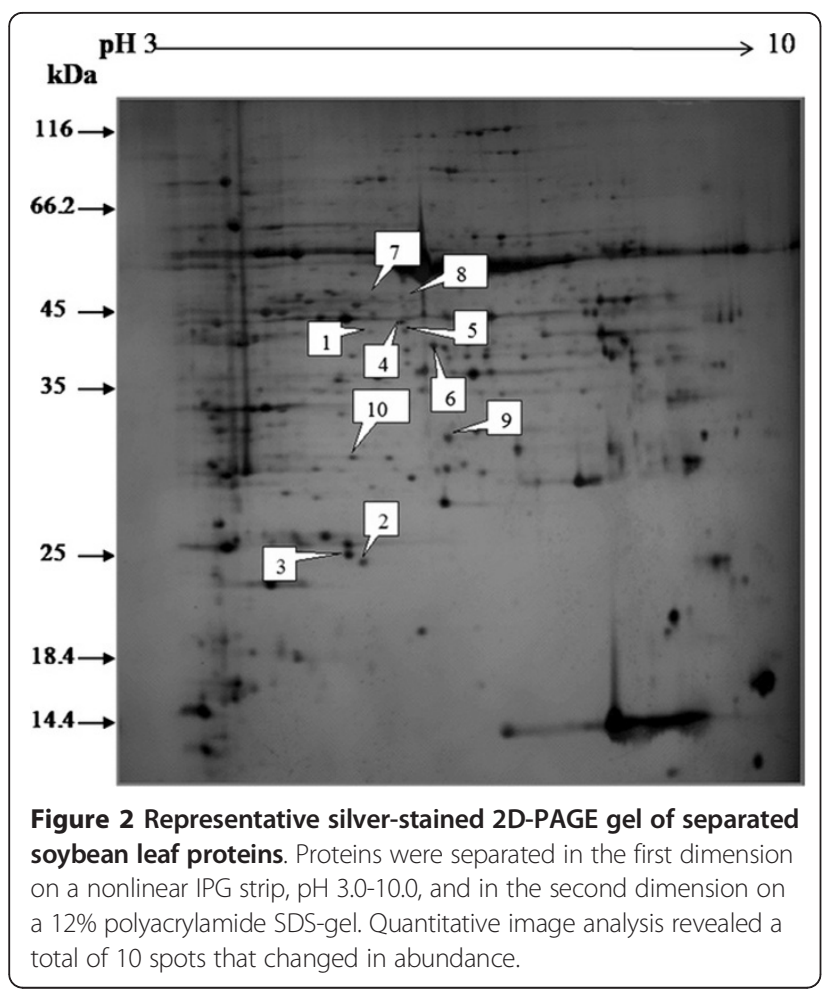

Changes of proteins in soybean leaves induced by cotton worm feeding

Soybean leaf proteins extracted $0 \mathrm{~h}, 6 \mathrm{~h}, 12 \mathrm{~h}$ and $24 \mathrm{~h}$ after cotton worm feeding and from the controls were analyzed by $2-\mathrm{DE}$. Three independent experiments were conducted to ensure that the changes in protein abundance at each timepoint were reproducible and significant. Software quantification showed that, although the protein expression profiles between the treated and control samples were similar, the abundance of some spots changed significantly with cotton worm feeding over time (Figures 2, 3 and 4). Ten spots showed changes in abundance in response to cotton worm feeding, most of which were up-regulated (Figures 2 and 3). The different expression patterns of the spots might imply different roles for these proteins in plant defense responses induced by cotton worm feeding.

\section{Identification of proteins involved in cotton worm- induced defense response in soybean}

All 10 differentially expressed proteins spots were subjected to in-gel digestion and analyzed by MALDI-TOFMS. The peptide mass fingerprints obtained were used to search the NCBI database using Mascot http://www. matrixscience.com. There were 11 proteins identified

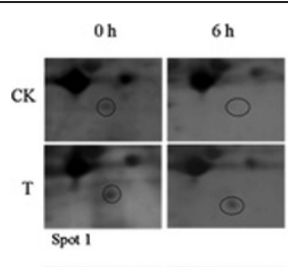

CK
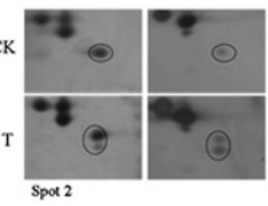

CK
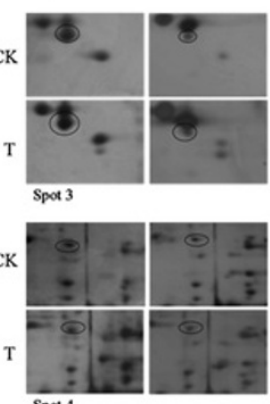

Spot 4

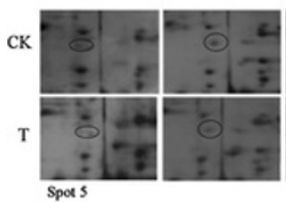

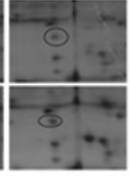

$12 \mathrm{~h}$
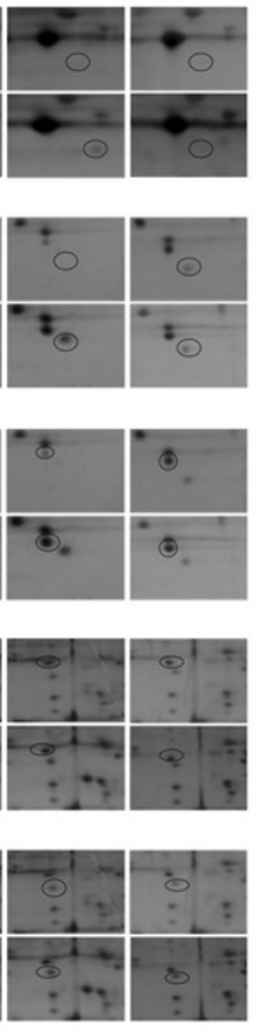

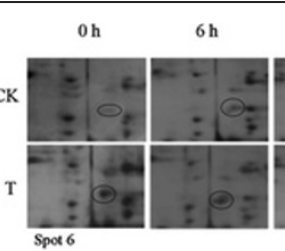

$12 \mathrm{~h}$

$24 \mathrm{~h}$
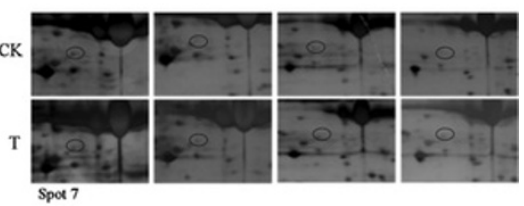

CK
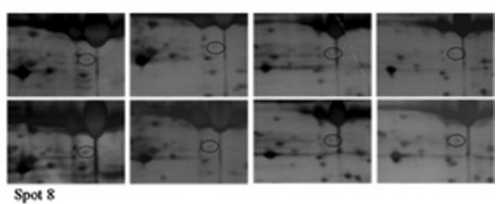

CK
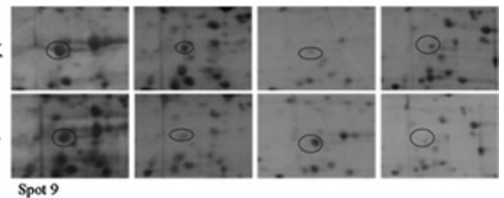

CK
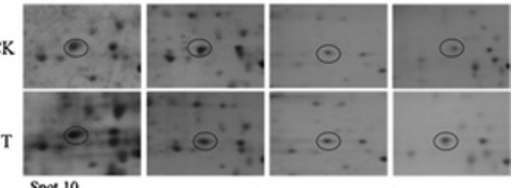

Figure 3 Enlarged maps of the 10 differentially expressed protein spots. CK: control; T: soybean leaves treated with cotton worm feeding 

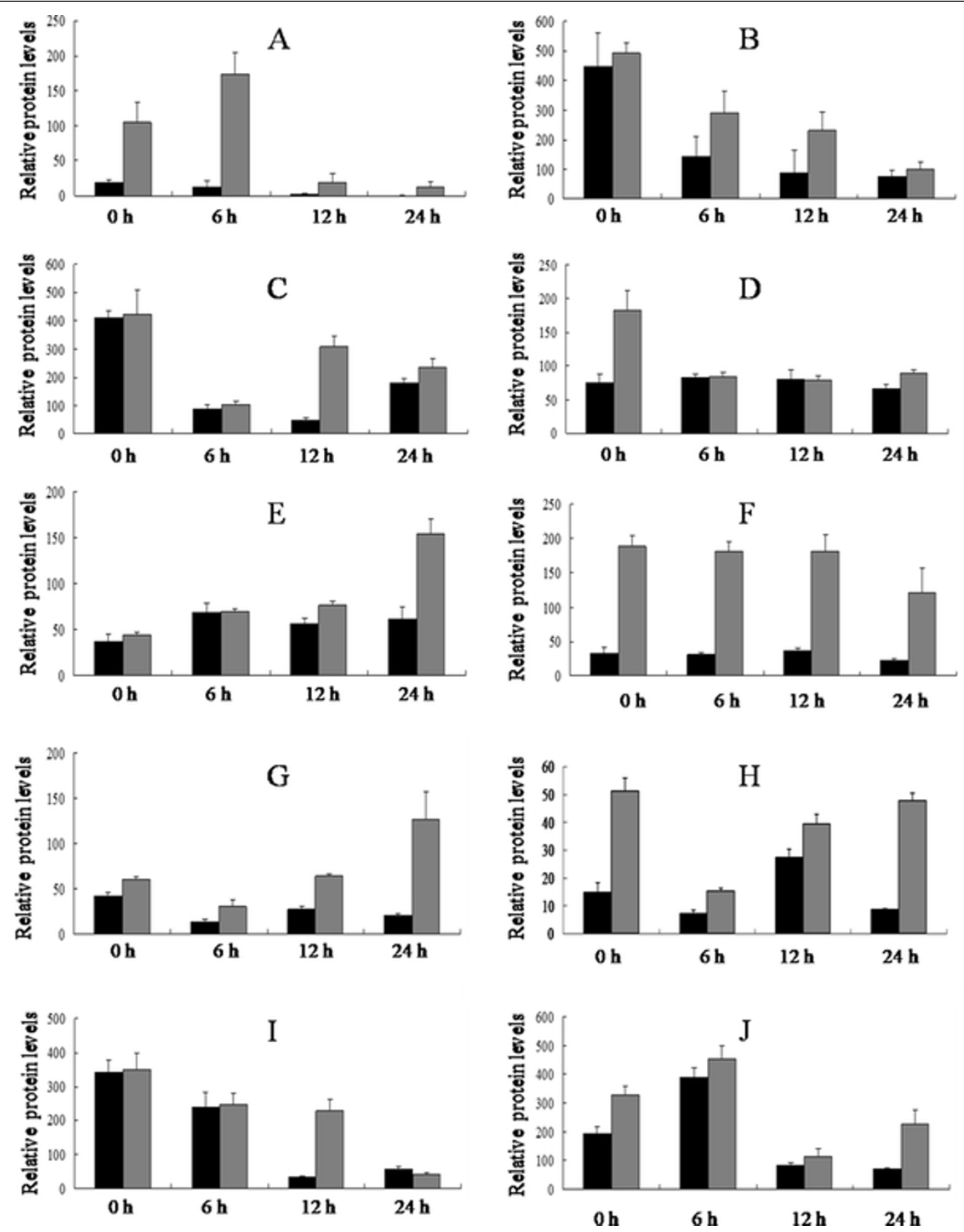

Figure 4 The volume changes of 10 differentially expressed spots. Control (black) and treated (gray). A - Jrepresent spot 1 - 10 respectively. Error bars represent the SD. The scales are different for the different proteins.

from these 10 protein spots (Table 1). Spots 5 and 10 contained two protein species, respectively. Spots 2 and 9 were identified as ribulose-1, 5 -bisphosphate carboxylase/oxygenase large subunit. When using 2-DE, comigrating proteins can present a major problem for quantitative protein expression comparison [38,39]. In this study, real-time RT-PCR was used to help determine which proteins showed altered expression. Occurrence of the same protein in several spots supposedly represents differently modified protein species that might be of biological relevance [38]. Interestingly, the observed $\mathrm{Mr} / \mathrm{PI}$ of some proteins was different from their theoretical $\mathrm{Mr} / \mathrm{PI}$. The reason might result from an unusual posttranslational modification. 
Table 1 Identification of differentially expressed protein spots by MALDI-TOF MS

\begin{tabular}{|c|c|c|c|c|c|c|}
\hline \multirow[t]{2}{*}{ Spot no. } & \multirow[t]{2}{*}{ Protein name } & \multicolumn{2}{|c|}{$\mathrm{Mr}(\mathrm{KDa}) / \mathrm{PI}$} & \multirow[t]{2}{*}{ Sequence coverage (\%) } & \multirow[t]{2}{*}{ Score } & \multirow[t]{2}{*}{ Accession no. } \\
\hline & & Theoretical & Experimental & & & \\
\hline 1 & serine/threonine kinase-related protein & $14.7 / 9.4$ & $42.0 / 6.0$ & 46 & 76 & gi|34099884 \\
\hline \multirow[t]{2}{*}{$2 / 9$} & ribulose-1,5- bisphosphate & $23.3 / 6.1$ & $24.0 / 7.7$ & 23 & 90 & gi|157812656 \\
\hline & carboxylase/oxygenase large subunit & $51.8 / 6.2$ & $31.1 / 6.81$ & 30 & 172 & gi|14599574 \\
\hline 3 & Vegetative storage protein $\mathrm{A}$ & $29.2 / 8.8$ & $24.4 / 6.1$ & 62 & 174 & gi|134145 \\
\hline 4 & cytosolic phosphoglycerate kinase & $42.3 / 5.7$ & $43.6 / 6.4$ & 26 & 103 & gi|9230771 \\
\hline 5 & ATP synthase beta subunit & $50.0 / 5.7$ & $42.4 / 6.4$ & 32 & 81 & gi|20269424 \\
\hline 5 & malate dehydrogenase & $36.1 / 8.2$ & $42.4 / 6.4$ & 28 & 68 & gi|5929964 \\
\hline 6 & phenylalanine ammonia-lyase & $46.5 / 6.0$ & $40.3 / 6.7$ & 56 & 347 & gi|81807 \\
\hline 7 & S-adenosylmethionine synthetase & $42.9 / 5.4$ & $47.4 / 6.1$ & 25 & 88 & gi|10443981 \\
\hline 8 & predicted protein & $60.3 / 5.8$ & $47.0 / 6.5$ & 24 & 75 & gi|168040478 \\
\hline 10 & ascorbate peroxidase & $27.1 / 5.7$ & $29.8 / 5.9$ & 45 & 110 & gi|12229897 \\
\hline 10 & 20 s proteasome alpha subunit & $27.4 / 5.8$ & $29.8 / 5.9$ & 41 & 104 & gi|12229897 \\
\hline
\end{tabular}

We verified the cotton worm-induced defense response profile of abundance-changed proteins at mRNA level by real-time qRT-PCR. The mRNA levels of most proteins were up-regulated in response to cotton worm feeding (Figures 4 and 5). ATP synthase beta subunit and malate dehydrogenase were located in the same spot, and the mRNA levels for both proteins were up-regulated, which indicated expression of both protein species in spot 5 was changed in response to cotton worm feeding. Similarly, expression of ascorbate peroxidase and $20 \mathrm{~S}$ proteasome alpha subunit in spot 10 both changed in response to cotton worm feeding.

Levels of mRNA are not always consistent with the levels of the corresponding proteins $[40,41]$. Three potential reasons for the lack of a strong correlation between mRNA and protein expression levels have been proposed: (i) translational regulation; Because of many complicated and varied post-transcriptional events, the transcriptome might not always be reflected at proteome levels [42-44]. (ii) differences in protein in vivo half-lives $[42,43]$; and (iii) significant experimental error, there is a significant amount of error and noise in both protein and mRNA experiments that limit our ability to get a clear picture.

\section{Differentially expressed proteins}

Spot 1 was up-regulated in response to cotton worm feeding, which was identified as serine/threonine kinase (STK)-related protein (Figure 4A and 5A). As a signal protein, STK regulates a variety of cellular processes $[45,46]$. This study found that STK involved in soybean defense responses induced by cotton worm feeding. Previously, it has been reported that STK was shown to be involved in plant defense responses and induced by low temperature, Soybean mosaic virus, and SA [47-49].
Spots 2 and 9 were up-regulated and were identified as ribulose-1,5-bisphosphate carboxylase/oxygenase (RubisCO) large subunit(Figures 4B, I and 5B). RubisCO is the most abundant protein in plants and plays a major role in photosynthesis. RubisCO large subunit is up-regulated under stress, which might be indicative of the protective and more active action of carbon assimilation machinery [50].

Spot 3 was identified as vegetative storage protein $\alpha$ (VSP $\alpha$ ). This protein was up-regulated at both protein and mRNA levels (Figures $4 \mathrm{C}$ and $5 \mathrm{C}$ ). The best-characterized VSPs are soybean VSP $\alpha$ and VSP $\beta$ VSPs are thought to serve as a transient reserve that sequesters unused amino acids during plant development. Once new seed production begins, stored VSPs presumably make nitrogen and other nutrients immediately available for seed development [51]. This hypothesis, however, was not supported by transgenic soybean in which VSP expression was abolished and seed production was unaffected even under nitrogen-deprived conditions [52]. Thus VSPs may serve other functions beyond sourcesink interaction or plant productivity. Arabidopsis VSP transcripts are induced by mechanical wounding, JA, insect herbivory, and osmotic and nutritional stresses [9,19,53-55], which is a common response shared by many genes encoding anti-insect proteins. Liu et al. found AtVSP2 is an anti-insect acid phosphatase [56]. Whether soybean VSP $\alpha$ has an anti-insect function needs further study.

Spot 4 showed up-regulation at $0 \mathrm{~h}$ and was identified as cytosolic phosphoglycerate kinase (PGK) (Figure 4D). It was up-regulated at all sample timepoints at the mRNA level (Figure 5D). PGK is an enzyme that catalyzes the formation of ATP from ADP and vice versa. In the second step of the second phase in glycolysis, 1,3bisphosphoglycerate is converted to 3-phosphoglycerate, 

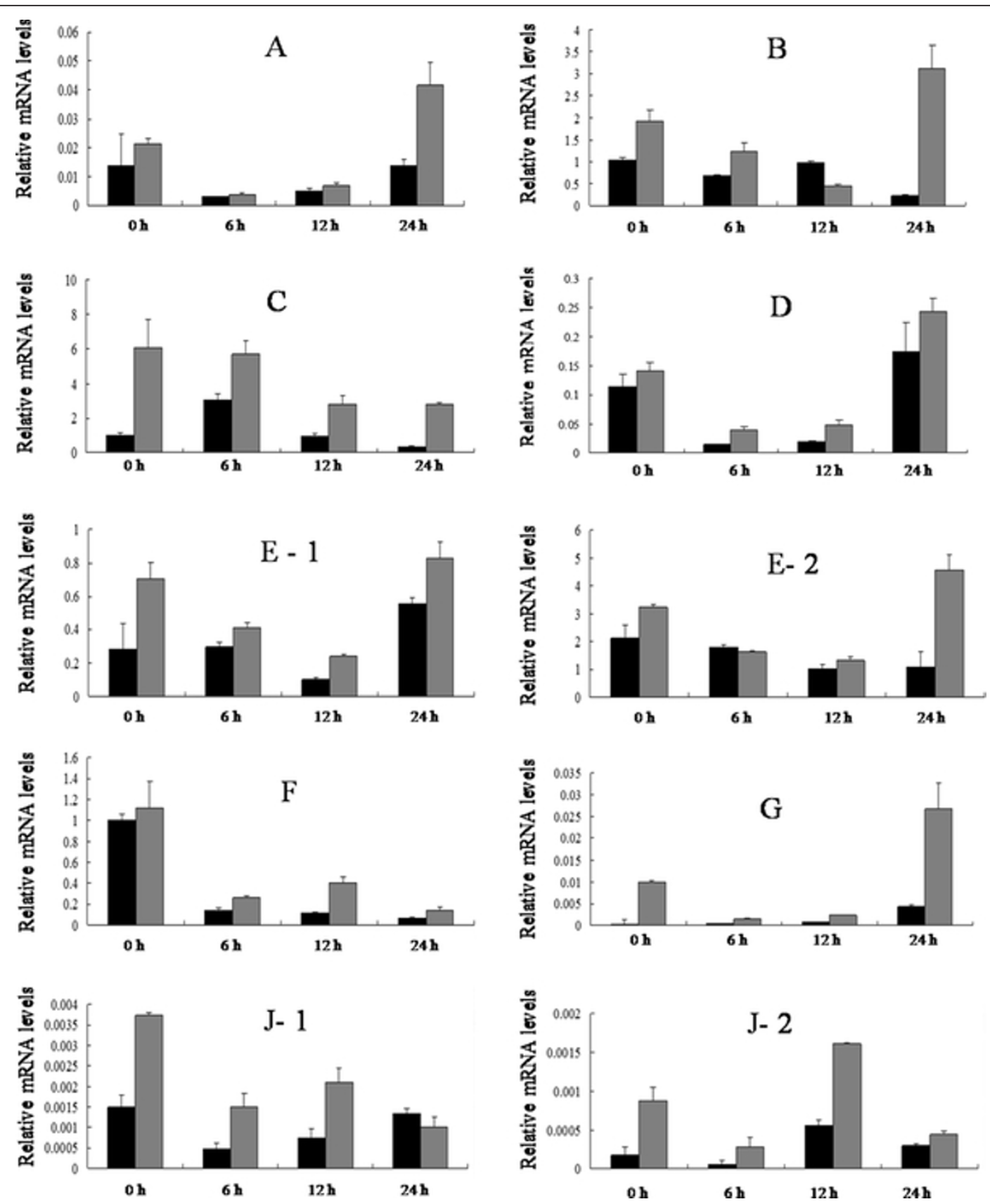

Figure $\mathbf{5}$ The expression of 10 differentially expressed spots at the corresponding mRNA level. A represents spot 1.B represents spot 2 and 9. C - Grepresent spot 3 - 7 respectively. J represents spot 10. A, serine/threonine kinase-related protein.B, ribulose-1,5- bisphosphate carboxylase/oxygenase large subunit. C, Vegetative storage protein A. D, cytosolic phosphoglycerate kinase.E- 1, ATP synthase beta subunit. E- 2, malate dehydrogenase. F, phenylalanine ammonia-lyase.G, S-adenosylmethionine synthetase.J- 1, ascorbate peroxidase. J- 2, 205 proteasome alpha subunit. Error bars represent the SD. The scales are different for the different genes.

forming one molecule of ATP. If the reverse occurs, one molecule of ADP is formed. This reaction is essential in most cells for ATP generation in aerobes, for fermentation in anaerobes, and for carbon fixation in plants. Under stress conditions, do plants need to energy has not yet been reported.
Spot 5 was identified as ATP synthase $\beta$ subunit and malate dehydrogenase (MDH). These proteins were upregulated at the mRNA level (Figure 5E-1 and 5E-2). ATP synthase is an important enzyme that generates energy for the cell to use through the synthesis of ATP. ATP synthase $\beta$ was up-regulated in the rice defense 
response induced by probenazole [39]. $\mathrm{MDH}$ is an enzyme in the citric acid cycle that catalyzes the conversion of malate into oxaloacetate (using NAD+) and vice versa (this is a reversible reaction). $\mathrm{MDH}$ is not to be confused with malic enzyme, which catalyzes the conversion of malate to pyruvate, producing NADPH. $\mathrm{MDH}$ is involved in many physiological activities, such as the organelle shuttle system, plant disease resistance, and metabolism of reactive oxygen species.

Spot 6 was identified as phenylalanine ammonialyase (PAL). This protein was up-regulated at both the protein and mRNA levels (Figures $4 \mathrm{~F}$ and $5 \mathrm{~F}$ ). It is clear that PAL plays a key role in induced disease resistance based on induction of its expression by pathogens or elicitors, and on studies using transgenic approaches in tobacco $[57,58]$. PAL is the first enzyme in the phenylpropanoid pathway. In plants, PAL can supply the precursors for lignin, flavonoid pigments, protectants, and furanocoumarin phytoalexins [59]. Lignin has a positive effect on plant resistance to insects. Based on its up-regulation in the soybean defense response induced by cotton worm feeding, PAL might play a key role in cotton worm-induced resistance.

Spot 7 was identified as S-adenosylmethionine synthetase (SAMS). This protein was up-regulated at both the protein and mRNA levels (Figure 4G and 5G). Previous studies showed that increased expression of SAMS was induced by mechanical wounding, JA, insect herbivory, chilling, and salinity stress [60-63]. SAMS is a key enzyme that catalyzes the formation of S-adenosylmethionine (SAM) from methionine and ATP. SAM is a precursor of polyamines and ET. Polyamines play important roles in plant defense to a variety of environmental stresses $[64,65]$. ET as a plant hormone that plays an important role in induced defense. Thus SAMS might play a key role in soybean induced resistance and warrants further study.

Spot 10 was identified as ascorbate peroxidase (APX) and $20 \mathrm{~S}$ proteasome $\alpha$ subunit. These proteins were upregulated at the mRNA level (Figure 5J-1 and 5J-2). APX is an enzyme in the ascorbate-glutathione cycle. The ascorbate-glutathione cycle is an important antioxidant protection system against $\mathrm{H}_{2} \mathrm{O}_{2}$ generated in different cell compartments. In this study, APX may contribute to induced resistance. Overexpression of the APX gene not only enhances the plant's antioxidant capacity, but also can enhance plant tolerance to drought, heat, salt and pathogens $[66,67]$. In eukaryotic cells, most proteins in the cytosol and nucleus are degraded via the ubiquitin-proteasome pathway. The $26 \mathrm{~S}$ proteasome is responsible for the degradation of damaged and misfolded proteins. A previous study showed that elicitation of defense reactions in tobacco cells by cryptogein, a proteinaceous elicitor of plant defense reactions, leads to a rapid and differential accumulation of transcripts corresponding to genes that encode defense-induced subunits of 20S proteasome [68].

In summary, all of the above proteins showed changed abundances induced by cotton worm feeding on soybean leaves. Thus the induced resistance might be a result of the combined effect of these proteins.

\section{Conclusions}

In order to better understand the defense response induced in soybean, we investigated the changes in the soluble proteome of soybean leaves damaged by cotton worm feeding using 2-DE and MALDI-TOF-MS. A total of 10 spots changed in abundance, from which 11 proteins were identified. These proteins are indicated to be involved in multiple physiological processes, including active oxygen removal, defense signal transduction and metabolism regulation. PAL and SAMS were up-regulated at both the protein and mRNA levels. It is clear that PAL plays a key role in induced disease resistance, and SAMS can catalyzes the production of many resistance-related material. They can be strongest candidates for further functional research.

\section{Materials and methods}

\section{Plant materials, growth conditions and treatments}

Seeds of soybean (Glycine max [L].Merr.cv. Nannong 99-10) were sown in $15 \mathrm{~cm}$ plastic pots that contained a sterile soil mixture (top soil:sand:vermiculite, 3:2:1). The seedlings were grown in a greenhouse maintained at 30 $\pm 5^{\circ} \mathrm{C}, 70 \pm 10 \% \mathrm{RH}$, and a $14 \mathrm{~h} / 10 \mathrm{~h}$ (day/night) photoperiod with supplementary metal-halide illumination. To prevent the interference of other insects, all potted plants were covered with gauze. The potted plants were watered once daily with the same volume of water. The developmental stages of soybean plants were defined as described by Fehr et al. [69].

Treatments of cotton worm (obtained from a colony maintained on an artificial diet) feeding and untreated (control) plants were applied to soybean plants at the V4 (vegetative stage with four nodes) stage of growth. Defoliation (about 20-30\%) was induced by placing three third-instar cotton worm larvae on the first trifoliate leaf for $48 \mathrm{~h}$, after which the larvae were removed. The leaves of control and treated plants at four sampling times $(0 \mathrm{~h}, 6 \mathrm{~h}, 12 \mathrm{~h}$ and $24 \mathrm{~h})$ after removal of the larvae were excised for identification of induced resistance, protein extraction and RNA extraction. There were three biological replications.

\section{Identification of induced resistance}

To evaluate soybean resistance induced by cotton worm, a dual-choice test and force-feeding experiment were 
conducted. In the dual-choice test, three to five leaves from each pair of experimental plants were arranged opposite each other at the margins of a porcelain dish $(30 \mathrm{~cm} \times 20 \mathrm{~cm})$. Ten cotton worm larvae, previously starved for $24 \mathrm{~h}$, were released into the middle area of the porcelain dish and allowed to feed for $12 \mathrm{~h}$. Leaf area was measured by a LICOR-3000 area meter (LICOR, Lincoln, NE). The consumed area in the control (C) and treatment $(\mathrm{T})$ was used to calculate the feedingpreference index $(\mathrm{PI})$, where $\mathrm{PI}=2 \mathrm{~T} /(\mathrm{T}+\mathrm{C})$ [70]. The $\mathrm{PI}$ values ranged from 0 to 2 , with $\mathrm{PI}=1$ indicating no feeding preference for either control or treatment leaves, PI $>1$ indicating preference for treatment leaves, and PI $<1$ indicating preference for control leaves. In the force-feeding experiment, control and treatment leaves were placed in $15-\mathrm{cm}$-diameter petri dishes, then five cotton worm larvae were placed in the dish. The relative growth rate (RGR) was calculated as RGR = (W1 - W2)/ $\mathrm{W} 1$, where $\mathrm{W} 1$ and $\mathrm{W} 2$ are the weights of five cotton worm larvae before placement in the dish and after feeding for $24 \mathrm{~h}$, respectively. Statistical analysis of the data was carried out using Microsoft Excel 2000. Each experiment was repeated thrice and the mean values and SD were calculated. Single factor ANOVA was carried out using SAS.

\section{Total protein extraction}

Total protein extraction for 2-DE was modified from the literature [39]. Frozen soybean leaves (0.2 g) were ground with liquid $\mathrm{N}_{2}$ in ice-cold acetone ( $2 \mathrm{ml}$ containing $10 \% \mathrm{w} / \mathrm{v}$ trichloroacetic acid $20 \mathrm{~m}$ DTT and 100 $\mathrm{mM}$ PMSF) after incubation at $-20^{\circ} \mathrm{C}$ for $1 \mathrm{~h}$, the proteins were precipitated by centrifugation at 19,000 $\times g$ for $15 \mathrm{~min}$ at $4^{\circ} \mathrm{C}$. The pellet was washed with $3 \mathrm{ml}$ icecold acetone containing $20 \mathrm{mM}$ DTT five times by centrifugation at $19,000 \times g$ for $15 \mathrm{~min}$ at $4^{\circ} \mathrm{C}$ until no chlorophyll was present in the acetone. The protein pellet was dried in vacuo and resuspended in lysis buffer (7 M urea, $2 \mathrm{M}$ thiourea, 4\% w/v CHAPS, $65 \mathrm{mM}$ DTT, $0.2 \% \mathrm{v} / \mathrm{v}$ carrier ampholyte $[\mathrm{pH} 3.0-10.0]$ and $1 \mathrm{mM}$ PMSF) by sonication. The insoluble debris was removed by ultracentrifugation at $45,000 \times g$ for $15 \mathrm{~min}$. The protein concentration was determined by the Bradford method with BSA as the standard [71]. The protein samples were stored at $-80^{\circ} \mathrm{C}$ until use.

\section{Two-dimensional electrophoresis}

The 2-DE experiment was performed essentially according to the Bio-Rad instruction (USA). To proceed with isoelectric focusing (IEF), Protein $(250 \mu \mathrm{g})$ was resuspended in lysis buffer containing $0.2 \%(\mathrm{v} / \mathrm{v})$ carrier ampholyte ( $\mathrm{pH} 3.0-10.0$ ), and $0.01 \%$ bromophenol blue and rehydrated with each $17 \mathrm{~cm}, \mathrm{pH}$ 3-10 nonlinear immobilized $\mathrm{pH}$ gradient (IPG) trip for $13 \mathrm{~h}$. IEF was carried out with a Protein IEF Cell (Bio-Rad) at $20^{\circ} \mathrm{C}$ in a stepwise manner: $250 \mathrm{~V}$ for $0.5 \mathrm{~h}, 500 \mathrm{~V}$ for $0.5 \mathrm{~h}$, $1000 \mathrm{~V}$ for $1 \mathrm{~h}, 2000 \mathrm{~V}$ for $1 \mathrm{~h}, 8000 \mathrm{~V}$ for $5 \mathrm{~h}$ and $8000 \mathrm{~V}$ for $55,000 \mathrm{~V} \mathrm{~h}$. After IEF, the IPGs were equilibrated by shaking at room temperature in equilibration buffer (6 M urea, 2\% [w/v] SDS, 30\% [v/v] glycerol, 50 $\mathrm{mM}$ Tris- $\mathrm{HCl}[\mathrm{pH} 8.8]$ ) containing $1 \%(\mathrm{w} / \mathrm{v})$ DTT for 20 min followed by equilibration in buffer containing $3 \%(\mathrm{w} / \mathrm{v})$ iodoacetamide for another $20 \mathrm{~min}$. The equilibrated IPGs were transferred to a $12 \%$ polyacrylamide gel. Electrophoresis was performed in Tris/glycine/SDS buffer on a Multiphor system (Amersham Pharmacia Biotech) according to the manufacturer's recommendations. For calibration, low-molecular weight marker proteins (Amersham Biosciences) were applied on the gel via a small piece of filter paper. After electrophoresis, the 2-DE gels were stained with silver [72]. The gels were fixed in $30 \%(\mathrm{v} / \mathrm{v})$ ethanol, $10 \%(\mathrm{v} / \mathrm{v})$ acetic acid for $30 \mathrm{~min}$, and sensitized for $30 \mathrm{~min}$ in $30 \%(\mathrm{v} / \mathrm{v})$ ethanol, $0.2 \%(\mathrm{w} / \mathrm{v})$ sodium thiosulfate and $6.8 \%(\mathrm{w} / \mathrm{v})$ sodium acetate, and then rinsed thrice in water, for 10 mimutes for each wash. Impregnated the gels with $0.25 \%(\mathrm{w} / \mathrm{v})$ silver nitrate for $20 \mathrm{~min}$, and then rinsed them twice for $1 \mathrm{~min}$ for each wash in water.

Transferred the gels in developer solution containing $2.5 \%(\mathrm{w} / \mathrm{v})$ sodium carbonate and $0.02 \%(\mathrm{v} / \mathrm{v})$ formaldehyde until the adequate degree of staining, then transferred them to $1.46 \%(\mathrm{w} / \mathrm{v})$ ethylenediaminetetraacetic acid disodium salt stop solution for 30 minutes, last washed the gels twice in water for $10 \mathrm{~min}$ for each wash.

\section{Gel image comparison and data analysis}

Spot detection, spot measurement, background subtraction and spot matching were performed specifically after silver-staining of the gels using PDQuest software. Following automatic spot detection, gel images were carefully edited. Before spot matching, one of the gel images was selected as the reference gel. The amount of a protein spot was expressed as the volume of that spot which was defined as the sum of the intensities of all pixels that made up the spot. In order to correct for variability owing to silver-staining and to reflect the quantitative variation in intensity of protein spots, the spot volumes were normalized as a percentage of the total volume of all spots present in the gel. The resulting data from image analysis were transferred to PDQuest software for querying protein spots that showed quantitative or qualitative variations. Only those with significant changes (quantitative changes more than two-fold in abundance) were used for further study. Statistical analysis of the data was carried out using Microsoft Excel 2000. The standard deviation (SD) was calculated from three spots in different gels. 
Table 2 Primer sequences used for qRT-PCR

\begin{tabular}{|c|c|c|c|}
\hline Spot no & Protein name & Forward primer $\left(5^{\prime} \rightarrow 3^{\prime}\right)$ & Reverse primer $\left(5^{\prime} \rightarrow 3^{\prime}\right)$ \\
\hline 1 & serine/threonine kinase related protein & GTGGCCAAGCTTCAACATAGAA & GGCTITGTTTGGTATGTATTCATAGA \\
\hline $2 / 9$ & ribulose-1,5-bisphosphate carboxylase/oxygenase large subunit & CGCGGTATTTATTTCACTCAGGAT & TCTCGGTCAGAGCAGGCATA \\
\hline 3 & Vegetative storage Protein $\alpha$ & GGACAAACAGGCCGTAACAGA & CTCTCGCTGCTGTITTGTATGAA \\
\hline 4 & cytosolic phosphoglycerate kinase & TTGCGAAGAAATGGCGACTA & CAAAGGCACGTTCAGATCGA \\
\hline 5 & ATP synthase beta subunit & GCGCCTGCTACGACATTTG & GGTTGGAGCATAGTTGAGGTTGA \\
\hline 5 & malate dehydrogenase & TGCCCTITITGCTGATGCT & TGCCCCAAGCCCAGAAC \\
\hline 6 & phenylalanine ammonialyase & TGCTCAAGGTTGTTGATAGGGAGTA & TCCACAAGCACTTGCCTTAGC \\
\hline 7 & S-adenosylmethionine synthetase & GAGACATGCACCAAGACCAACA & ATTTCGCGGCATGTGTCA \\
\hline 8 & predicted protein & AACAAGTGCAAGTTCGAATCAATG & ACGACGCCGTAGAGATCGAT \\
\hline 10 & ascorbate peroxidase & CGCTCCTCTAATGCTCCGTTT & AATCGGCGTAGCTCAAAATAGG \\
\hline \multirow[t]{2}{*}{10} & 205 proteasome alpha subunit $\mathrm{A}$ & TTCTTCGTTGCGCTTITTCC & CCTCGACTCATTITGGCCTAA \\
\hline & tubulin & GGAGTTCACAGAGGCAGAG & CACTTACGCATCACATAGCA \\
\hline
\end{tabular}

Gel images used for statistical analysis were obtained from three independent biological repeats.

\section{Protein identification and database searches}

Silver-stained protein spots were excised, washed with $50 \% \mathrm{v} / \mathrm{v}$ acetonitrile in $0.1 \mathrm{M} \mathrm{NH}_{4} \mathrm{HCO}_{3}$ and dried in a vacuum centrifuge [73]. Gel fragments were reduced in $20 \mu \mathrm{l}$ of $10 \mathrm{mM}$ DTT with $0.1 \mathrm{M} \mathrm{NH}_{4} \mathrm{HCO}_{3}$ for $45 \mathrm{~min}$ at $55^{\circ} \mathrm{C}$. After cooling, the DTT solution was replaced with $55 \mathrm{mM}$ iodoacetamide in $0.1 \mathrm{M} \mathrm{NH}_{4} \mathrm{HCO}_{3}$. After washing, the dried gel pieces were rehydrated in $10 \mu \mathrm{l}$ digestion buffer containing $25 \mathrm{mM} \mathrm{NH}_{4} \mathrm{HCO}_{3}$ and 12.5 $\mathrm{ng} / \mathrm{ml}$ trypsin (Promega, Madison, WI, USA) and incubated at $37^{\circ} \mathrm{C}$ overnight. Tryptic-digested peptides were extracted. Samples were analyzed by MALDI-TOF-MS and tandem TOF/TOF MS on a time-of-flight Autolex III mass spectrometer (Bruker Daltonics, Bremen, Germany). Peptide mass maps were acquired in positive reflection mode, averaging 400 laser shots per MALDITOF spectrum (resolution was 15,000-20,000). The Bruker calibration mixtures were used to calibrate the spectrum to a mass tolerance within $0.1 \mathrm{Da}$.

The peak list file containing the $\mathrm{m} / \mathrm{z}$ ratios of precursor ions and MS/MS fragmented ions was used in searches of the web-based search engine Mascot http:// www.matrixscience.com against the most recent database in the National Center for Biotechnology Information (NCBI). The initial search used green plants as the taxon. The other parameters for the searches were: enzyme trypsin; one or two missed cleavages; variable modifications of carbamidomethyl (Cys), oxidation (Met), and pyro-Glu (Nterminal Glu); peptide tolerance of 0.1-0.5 Da; MS/MS tolerance of 0.2 Da; peptide charge of $1+2+$; and monoisotopic. Only significant hits, as defined by the MASCOT probability analysis $(P$ $<0.05)$, were accepted.

\section{Real-time quantitative RT-PCR}

Total RNA was isolated from frozen soybean leaves by the TRIzol method with a total RNA Kit (Tiangen, China). Reverse transcription reactions were performed with an oligo $(\mathrm{dT})_{18}$ primer and ReverTra Ace Moloney murine leukemia virus reverse transcriptase (Toyobo, Japan) according to the manufacturer's instructions. All primers were designed based on the sequences obtained using BLASTN in the NCBI database or soybean genome sequences database http://www.phytozome.net. Real-time qRT-PCR was performed on an ABI 7500 real time PCR system (Applied Biosystems, USA) using the SYBR Green Realtime Master Mix (Toyobo, Japan). Tubulin (GenBank accession no. AY907703), a constitutively expressed gene with approximately equal PCR efficiency in all samples, was used as the reference gene. Data were analyzed with SDS 2.0 software (Applied Biosystems). The primer sequences used for real-time qRTPCR are listed in Table 2.

\section{Acknowledgements}

This work was supported in part by the National Basic Research Program of China (973 Program) (nos. 2010CB125906 and 2009CB118400), and the National Natural Science Foundation of China (nos. 30800692, 31000718, and 31171573)

\section{Author details}

${ }^{1}$ National Center for Soybean Improvement, National Key Laboratory of Crop Genetics and Germplasm Enhancement, Nanjing Agricultural University, Nanjing 210095, China. ${ }^{2}$ College of Chemical and Material Engineering, Quzhou University, Quzhou 324000, China.

\section{Authors' contributions}

RF designed and performed research, analyzed data and wrote the manuscript. HW participates in the design of the study. YW participate in experiment that determination of induce resistance by cotton worm feeding in soybean. DY designed research and revised the manuscript. All the authors have read and approved the final manuscript.

\section{Competing interests}

The authors declare that they have no competing interests. 
Received: 28 October 2011 Accepted: 8 March 2012

Published: 8 March 2012

\section{References}

1. Krishnan HB: Biochemistry and molecular biology of soybean seed storage proteins. New Seeds 2000, 2:1-25.

2. Thelen JJ, Ohlrogge JB: Metabolic engineering of fatty acid biosynthesis in plants. Metab Eng 2002, 4:12-21.

3. Cui ZL, Gai JY: A study of leaf-feeding insect species on soybeans in Nanjing area. Soybean Science 1997, 16:12-20.

4. Zhan QW, Gai JY, Zhang YM, Sun ZD: Development and expression process of inheritance of resistance to cotton worm (prodinia litura) in soybeans. Acta Genetica Sinica 2001, 28:956-963.

5. Zhang PJ, Shu JP, Fu CX, Zhou Y, Hu Y, Zalucki MP, Liu SS: Trade-offs between constitutive and induced resistance in wild crucifers shown by a natural, but not an artificial, elicitor. Oecologia 2008, 157:83-92.

6. Agrawal AA: Induced responses to herbivory and increased plant performance. Science 1998, 279:1201-1202.

7. Attaran E, Zeier TE, Griebel T, Zeier J: Methyl salicylate production and jasmonate signaling are not essential for systemic acquired resistance in Arabidopsis. The Plant Cell 2009, 21:954-971.

8. De Vos M, Van Zaanen W, Koornneef A, Korzelius JP, Dicke M, Van Loon LC, Pieterse CMJ: Herbivore-induced resistance against microbial pathogens in Arabidopsis. Plant Physiol 2006, 142:352-363.

9. Stotz HU, Pittendrigh BR, Kroymann J, Weniger K, Fritsche J, Bauke A, Mitchell-Olds T: Induced plant defense responses against chewing insects. Ethylene signaling reduces resistance of Arabidopsis against Egyptian cotton worm but not diamondback moth. Plant Physiol 2000, 124:1007-1018.

10. Wu J, Hettenhausen C, Meldau S, Baldwin IT: Herbivory rapidly activates MAPK signaling in attacked and unattacked leaf regions but not between leaves of Nicotiana attenuata. Plant Cell 2007, 19:1096-1122.

11. Egusa M, Akamatsu H, Tsuge T, Otani H, Kodama M: Induced resistance in tomato plants to the toxin-dependent necrotrophic pathogen Alternaria alternata. Physiol Mol Plant Pathol 2008, 73:67-77.

12. Luo Y, Caldwell KS, Wroblewski T, Wright ME, Michelmore RW: Proteolysis of a negative regulator of innate immunity is dependent on resistance genes in tomato and Nicotiana benthamiana and induced by multiple bacterial effectors. Plant Cell 2009, 21:2458-2472.

13. Senthil-Nathan S, Kalaivani K, Choi MY, Paik CH: Effects of jasmonic acidinduced resistance in rice on the plant brownhopper, Nilaparvata lugens Stl (Homoptera: Delphacidae). Pestic Biochem Physiol 2009, 95:77-84.

14. Bi JL, Felton GW, Mueller AJ: Induced resistance in soybean to Helicoverpa zea: Role of plant protein quality. Chem Ecol 1994, 20:183-198.

15. Lin $H$, Kogan M: Influence of induced resistance in soybean on the development and nutrition of the soybean looper and the Mexican bean beetle. Entomol Exp Appl 1990, 55:131-138.

16. Srinivas P, Danielson SD, Smith CM, Foster JE: Cross-resistance and resistance longevity as induced by bean leaf beetle, Cerotoma trifurcata and soybean looper, Pseudoplusia includens herbivory on soybean. Insect Sci 2001, 1:1-5.

17. Kraemer ME, Rangappa M, Gade W, Benepal PS: Induction of trypsin inhibitors in soybean leaves by Mexican bean beetle (Coleoptera: Coccinellidae) defoliation. Econ Entomol 1987, 80:237-241.

18. Kessler A, Baldwin IT: Defensive function of herbivore-induced plant volatile emissions in nature. Science 2001, 291:2141-2144.

19. Reymond P, Farmer EE: Jasmonate and salicylate as global signals for defense gene expression. Curr Opin Plant Biol 1998, 1:404-411.

20. Ton J, Van Pelt JA, Van Loon LC, Pieterse CMJ: Differential effectiveness of salicylate-dependent and jasmonate/ethylene-dependent induced resistance in Arabidopsis. Mol Plant Microbe Interact 2002, 15:27-34.

21. Van Loon JJA, de Boer JG, Dicke M: Parasitoid-plant mutualism: parasitoid attack of herbivore increases plant reproduction. Entomol Exp Appl 2000, 97:219-227.

22. Glazebrook J: Contrasting mechanisms of defense against biotrophic and necrotrophic pathogens. Annu Rev Phytopathol 2005, 43:205-227.

23. Halitschke R, Baldwin IT: Antisense LOX expression increases herbivore performance by decreasing defense responses and inhibiting growthrelated transcriptional reorganization in Nicotiana attenuata. Plant J 2003, 36:794-807.
24. Thomma BPHJ, Penninckx IAMA, Cammue B, Broekaert WF: The complexity of disease signaling in Arabidopsis. Curr Opin Immunol 2001, 13:63-68.

25. Howe GA: Jasmonates as signals in the wound response. Plant Growth Regulation 2004, 23:223-237.

26. Zavala JA, Patankar AG, Gase K, Hui D, Baldwin IT: Manipulation of endogenous trypsin proteinase inhibitor production in Nicotiana attenuata demonstrates their function as antiherbivore defenses. Plant Physiol 2004, 134:1181-1190.

27. Dicke M, Agrawal AA, Bruin J: Plants talk, but are they deaf? Trend Plant Sci 2003, 8:403-405.

28. Heil M, Silva Bueno JC: Within-plant signaling by volatiles leads to induction and priming of an indirect plant defense in nature. Proc Natl Acad Sci 2007, 104:5467-5472.

29. Lee S, Lee EJ, Yang EJ, Lee JE, Park AR, Song WH, Park OK: Proteomic identification of annexins, calcium-dependent membrane binding proteins that mediate osmotic stress and abscisic acid signal transduction in Arabidopsis. Plant Cell 2004, 16:1378-1391.

30. Salekdeh GH, Siopongco J, Wade LJ, Ghareyazie B, Bennett J: A proteomic approach to analyzing drought-and salt-responsiveness in rice. Field Crops Res 2002, 76:199-219.

31. Yao WH: Biology characteristics of Prodenia litura. Entomol J East China 2005, 14:122-127.

32. Ruohom ki K, Hanhim ki S, Haukioja E, Iso-livari L, Neuvonen S, Niemel P, Suomela J: Variability in the efficacy of delayed inducible resistance in mountain birch. Entomol Exp Appl 1992, 62:107-115.

33. Roland J, Myers JH: Improved insect performance from host-plant defoliation: winter moth on oak and apple. Ecol Entomol 1987, 12:409-414

34. Gibberd R, Edwards PJ, Wratten SD: Wound-induced changes in the acceptability of tree-foliage to Lepidoptera: within-leaf effects. Oikos 1988, 51:43-47.

35. Green TR, Ryan CA: Wound-induced proteinase inhibitor in plant leaves: a possible defense mechanism against insects. Science 1972, 175:776-777.

36. Karban R, Carey JR: Induced resistance of cotton seedlings to mites. Science 1984, 225:53-54.

37. Underwood NC: The timing of induced resistance and induced susceptibility in the soybean-Mexican bean beetle system. Oecologia 1998, 114:376-381.

38. Krah A, Wessel R, Plei ner KP: Assessment of protein spot components applying correspondence analysis for peptide mass fingerprint data. Proteomics 2004, 4:2982-2986.

39. Lin YZ, Chen HY, Kao R, Chang SP, Chang SJ, Lai EM: Proteomic analysis of rice defense response induced by probenazole. Phytochemistry 2008, 69:715-728.

40. Gygi SP, Rochon Y, Franza BR, Aebersold R: Correlation between protein and mRNA abundance in yeast. Mol Cell Biol 1999, 19:1720-1730.

41. Ideker T, Thorsson V, Ranish JA, Christmas R, Buhler J, Eng JK, Bumgarner R, Goodlett DR, Aebersold R, Hood L: Integrated genomic and proteomic analyses of a systematically perturbed metabolic network. Science 2001, 292:929-934

42. Beyer A, Hollunder J, Nasheuer HP, Wilhelm T: Post-transcriptional expression regulation in the yeast Saccharomyces cerevisiae on a genomic scale. Mol Cell Proteomics 2004, 3:1083-1092.

43. Greenbaum D, Colangelo C, Williams K, Gerstein M: Comparing protein abundance and mRNA expression levels on a genomic scale. Genome Biol 2003, 4:117-124.

44. Nie L, Wu G, Zhang W: Correlation of mRNA expression and protein abundance affected by multiple sequence features related to translational efficiency in Desulfovibrio vulgaris: a quantitative analysis. Genetics 2006, 174:2229-2243.

45. Canova MJ, Kremer L, Molle V: pETPhos: a customized expression vector designed for further characterization of Ser/Thr/Tyr protein kinases and their substrates. Plasmid 2008, 60:149-153.

46. Wang XQ, Yang PF, Liu Z, Liu WZ, Hu Y, Chen H, Kuang TY, Pei ZM, Shen SH, He YK: Exploring the mechanism of Physcomitrella patens desiccation tolerance through a proteomic strategy. Plant Physiol 2009, 149:1739-1750.

47. Chen $L R$, Markhart AH, Shanmugasundaram S, Lin TY: Early developmental and stress responsive ESTs from mungbean, Vigna radiata (L.) Wilczek, seedlings. Plant Cell Reports 2008, 27:535-552. 
48. Jeong RD, Lim WS, Kwon SW, Kim KH: Identification of Glycine max genes expressed in response to Soybean mosaic virus infection. Plant Pathol 2005, 21:47-54.

49. Thompson GA, Goggin FL: Transcriptomics and functional genomics of plant defence induction by phloem-feeding insects. Exp Bot 2006, 57:755-766.

50. Sengupta S, Majumder AL: Insight into the salt tolerance factors of a wild halophytic rice, Porteresia coarctata: a physiological and proteomic approach. Planta 2009, 229:911-929.

51. Wittenbach VA: Purification and characterization of a soybean leaf storage glycoprotein. Plant Physiol 1983, 73:125-129.

52. Staswick PE, Zhang Z, Clemente TE, Specht JE: Efficient down-regulation of the major vegetative storage protein genes in transgenic soybean does not compromise plant productivity. Plant Physiol 2001, 127:1819-1826.

53. Berger S, Mitchell-Olds T, Stotz HU: Local and differential control of vegetative storage protein expression in response to herbivore damage in Arabidopsis thaliana. Physiol Plant 2002, 114:85-91.

54. Mason HS, Mullet JE: Expression of two soybean vegetative storage protein genes during development and in response to water deficit, wounding, and jasmonic acid. Plant Cell 1990, 2:569-579.

55. Xie DX, Feys BF, James S, Nieto-Rostro M, Turner JG: COI1: an Arabidopsis gene required for jasmonate-regulated defense and fertility. Science 1998, 280:1091-1094.

56. Liu Y, Ahn JE, Datta S, Salzman RA, Moon J, Huyghues-Despointes B, Pittendrigh B, Murdock LL, Koiwa H, Zhu-Salzman K: Arabidopsis vegetative storage protein is an anti-insect acid phosphatase. Plant Physiol 2005, 139:1545-1556.

57. Howles PA, Sewalt VJH, Paiva NL, Elkind Y, Bate NJ, Lamb C, Dixon RA: Overexpression of $\mathrm{L}$-phenylalanine ammonia-lyase in transgenic tobacco plants reveals control points for flux into phenylpropanoid biosynthesis. Plant Physiol 1996, 112:1617-1624.

58. Shadle GL, Wesley SV, Korth KL, Chen F, Lamb C, Dixon RA: Phenylpropanoid compounds and disease resistance in transgenic tobacco with altered expression of-phenylalanine ammonia-lyase. Phytochemistry 2003, 64:153-161.

59. Hahlbrock K, Scheel D: Physiology and molecular biology of phenylpropanoid metabolism. Ann Rev Plant Biol 1989, 40:347-369.

60. Arimura G, Ozawa R, Nishioka T, Boland W, Koch T, Kuhnemann F, Takabayashi J: Herbivore induced volatiles induce the emission of ethylene in neighboring lima bean plants. Plant J 2002, 29:87-98.

61. Cui S, Huang F, Wang J, Ma X, Cheng Y, Liu J: A proteomic analysis of cold stress responses in rice seedlings. Proteomics 2005, 5:3162-3172.

62. Espartero J, Pintor-Toro JA, Pardo JM: Differential accumulation of Sadenosylmethionine synthetase transcripts in response to salt stress. Plant Mol Biol 1994, 25:217-227.

63. Ji W, Li Y, Li J, Dai C, Wang X, Bai X, Cai H, Yang L, Zhu Y: Generation and analysis of expressed sequence tags from $\mathrm{NaCl}$-treated Glycine soja. BMC Plant Biol 2006, 6:4-10.

64. Tassoni A, Franceschetti M, Bagni N: Polyamines and salt stress response and tolerance in Arabidopsis thaliana flowers. Plant Physiol Biochem 2008, 46:607-613.

65. Tiburcio AF, Besford RT, Capell T, Borrell A, Testillano PS, Risueno MC: Mechanisms of polyamine action during senescence responses induced by osmotic stress. Exp Bot 1994, 45:1789-1800.

66. Sarowar S, Kim EN, Kim EN, Kim YJ, Ok SH, Kim KD, Hwang BK, Shin JS: Overexpression of a pepper ascorbate peroxidase-like 1 gene in tobacco plants enhances tolerance to oxidative stress and pathogens. Plant Sci 2005, 169:55-63.

67. Shi WM, Muramoto Y, Ueda A, Takabe T: Cloning of peroxisomal ascorbate peroxidase gene from barley and enhanced thermotolerance by overexpressing in Arabidopsis thaliana. Gene 2001, 273:23-27.

68. Suty L, Lequeu J, Lan on A, Etienne P, Petitot AS, Blein JP: Preferential induction of $20 \mathrm{~S}$ proteasome subunits during elicitation of plant defense reactions: towards the characterization of "plant defense proteasomes". Biochem Cell Biol 2003, 35:637-650.

69. Fehr WR, Burmood CE, Pennington DT: Stage of Development Descriptions for Soybeans, Glycine Max (L.) Merrill1. Crop Sci 1971, 11:929-931.

70. Kogan M: Feeding and nutrition of insects associated with soybeans. 2. Soybean resistance and host preferences of the Mexican bean beetle, Epilachnavarivest. Ann Entomol Soc Am 1972, 65:675-683.
71. Bradford MM: A rapid and sensitive method for the quantitation of microgram quantities of protein utilizing the principle of protein-dye binding. Anal Biochem 1976, 72:248-254.

72. Blum H, Beier H, Gross HJ: Improved silver staining of plant proteins, RNA and DNA in polyacrylamide gels. Electrophoresis 1987, 8:93-99.

73. Hellman U, Wernstedt C, Gonez J, Heldin CH: Improvement of an "In-Gel" digestion procedure for the micropreparation of internal protein fragments for amino acid sequencing. Anal Biochem 1995, 224:451-455.

doi:10.1186/1477-5956-10-16

Cite this article as: Fan et al: Proteomic analysis of soybean defense response induced by cotton worm (prodenia litura, fabricius) feeding. Proteome Science 2012 10:16.

\section{Submit your next manuscript to BioMed Central and take full advantage of:}

- Convenient online submission

- Thorough peer review

- No space constraints or color figure charges

- Immediate publication on acceptance

- Inclusion in PubMed, CAS, Scopus and Google Scholar

- Research which is freely available for redistribution 